\title{
PENGENDALIAN INTERNAL TERHADAP KREDIT CEPAT AMAN (KCA) PADA PT. PEGADAIAN CABANG MEGA MAS MANADO
}

\author{
Iin Febrianti Usman ${ }^{1}$, Inggriani Elim ${ }^{2}$, Robert Lambey ${ }^{3}$ \\ 1,2,3 Jurusan Akuntansi, Fakultas Ekonomi dan Bisnis, Universitas Sam Ratulangi, J1. Kampus Unsrat, Manado, \\ 95115, Indonesia
}

E-mail : iinfebrianti272@yahoo.co.id

\begin{abstract}
PT. Pegadaian are one of the formal institutions in Indonesia which under the law are allowed to do the financing by the form of quick credit distribution securely on the basis of legal pawn. The purpose to find out the internal control system against Secured Fast Credit (KCA) at PT. Pegadaian Branch Mega Mas Manado. The method used in this research is descriptive qualitative method. The data used in this study are primary data and secondary data, where the primary data obtained from the results of interview researchers with resource persons, as: interviews with finance staff and operational departments related to internal control. Data processing techniques used are interview techniques, observation, and documentation. Based on the results of research Scope of discussion on the internal control of fast credit secured at PT. Pegadaian Branch Mega Mas Manado includes a discussion related to the elements of internal control fast credit secured, namely a separate organizational structure of functional responsibilities, authority systems and record-keeping procedures that provide sufficient laws of wealth, debt, income and expenses, healthy practices in carrying out the duties and functions of each organizational unit and employees of a quality in accordance with their responsibilities.
\end{abstract}

Keywords : Internal Control and PT. Pegadaian

\section{PENDAHULUAN}

Pengendalian internal dalam perusahaan adalah untuk menjaga dan memastikan setiap aktivitas dalam perusahaan sesuai dan sejalan dengan tujuan perusahaan. Agar tetap unggul ditengah-tengah ketatnya persaingan bisnis, maka performa yang baik ini dihasilkan dari adanya suatu sistem pengendalian internal. Menurut COSO yang dikutip oleh Hesty (2013:11) Pengendalian internal adalah suatu proses, melibatkan seluruh anggota organisasi, dan memiliki tujuan utama yaitu efektifitas, efesiensi operasional, kehandalan laporan keuangan, dan kepatuhan atas hukum dan peraturan yang berlaku.

Suatu organisasi akan melakukan aktivitas kerja dengan baik jika memiliki pengendalian internal yang efektif. Pengendalian Internal yang efektif akan membantu manajemen dalam mengendalikan kegiatan perusahaan sehingga dapat mencegah terjadinya kesalahan dan penyelewengan. Pengendalian internal berfungsi untuk menjaga kekayaan perusahaan untuk memeriksa ketelitian dan keandalan data akuntansi, mendorong efisiensi, dan mendorong dipatuhinya kebijakan manajemen. Baik buruknya pelaksanaan pengendalian internal sangat berpengaruh terhadap laporan keuangan yang dihasilkan.

Kredit merupakan salah satu cara untuk membantu masyarakat dalam mendapatkan pinjaman dana. Berkaitan dengan kebutuhan dana bagi masyarakat untuk kegiatan konsumsi ataupun untuk menambah modal usaha, maka bermunculan permintaan kredit yang dapat digunakan masyarakat dalam membuka usaha sedangkan kredit konsumsi digunakan oleh masyarakat untuk mengkonsumsi barang tertentu. Kredit yang dibutuhkan oleh masyarakat dapat diberikan oleh lembaga jasa keuangan baik jasa keuangan perbankan maupun jasa keuangan non bank salah satunya adalah PT. Pegadaian yang selama ini dikenal dekat dengan 
masyarakat bila dibandingkan dengan bank yang fungsinya sama - sama dapat membantu melepaskan beban keuangan.

Meningkatkanya jumlah kredit oleh masyarakat memberi peluang bagi PT. Pegadaian sebagai alternative untuk menggunakan jasa keuangan ini, khususnya bagi masyarakat yang memiliki ekonomi kebawah yang sangat membutuhkan pinjaman dalam waktu singkat serta tidak menyulitkan mereka. Dalam menentukan jumlah penyaluran kredit gadai maka pegadaian akan dipengaruhi oleh kondisi eksternal, faktor internal yang dimaksud bagaimana perusahaan dapat mengelola dengan baik seperti manajemen asset perusahaan, factor $5 \mathrm{C}$ (character, capacity, capital, collateral dan condition of economy) manajemen kredit.

Kredit Cepat Aman (KCA), adalah salah satu produk andalan pegadaian, KCA ini berupa produk pinjaman dana yang disalurkan ke masyarakat dengan satu harapan masyarakat dapat memanfaatkannya untuk berbagai kepentingan ekonomi yang dapat meningkatkan pertumbuhan ekonomi secara makro. KCA merupakan pemberian kredit kepada masyarakat dalam jangka waktu tertentu atas dasar hukum gadai yang pengembaliannya dilakukan dengan membayar uang pinjaman disertai biaya sewa modalnya.

Masalah yang sering terjadi dalam KCA ini ialah adanya kredit bermasalah yang menimbulkan jatuh tempo. Kredit yang bermaslah ini dapat menggaggu kelancaran usaha dalam perusahaan. Dengan terselenggaranya sistem pengendalian internal yang memadai, terutama dalam bidang perkreditan berarti perusahaan dapat menjaga kelangsungan hidup usahanya. Sistem pengendalian intern dalam memberikan kredit yang digunakan berdasarkan pada unsur pengendalian intern menurut COSO (Committee of Sponsoring Organization). Penelitian ini bertujuan untuk mengetahui system pengendalian internal terhadap kredit cepat aman pada perusahaan yang berfokus dalam penggadaian di perusahaan.

\section{TINJAUAN PUSTAKA}

\subsection{Konsep Akuntansi}

Akuntansi pada dasarnya akan menghasilkan informasi dari sebuah system akuntansi yang ada di dalam sebuah entitas atau organisasi bisnis yang disebut dengan informasi akuntansi yang akan dimanfaatkan oleh pengguna seperti masyarakat umum, masyarakat intelektual (termasuk di dalamnya mahasiswa atau peneliti) dan para pengambil keputusan bisnis dalam organisasi (Pontoh, 2013:2). Rahman Pura (2013), menyatakan akuntansi dapat pula didefinisikan sebagai seni pencatatan, penggolongan, peringkasan, dan pelaporan transaksi yang bersifat keuangan yang terjadi dalam perusahaan. Ahmad dan Abdullah (2012: 17). Akuntansi (accounting) merupakan suatu kegiatan atau jasa yang berfungsi menyediakan informasi kuantitatif terutama yang bersifat keuangan mengenai kesatuan - kesatuan ekonomi tertentu kepada pihak - pihak yang berkepentingan untuk digunakan sebagai bahan pertimbangan dalam pengambilan keputusan - keputusan ekonomi.

Akuntansi berasal dari bahasa inggris yaitu " to account" yang artinya menghitung atau mempertanggung jawabkan sesuatu yang ada kaitannya dengan pengelolaan bidang keuangan dari suatu perusahaan kepada pemiliknya atas kepercayaan yang telah diberikan kepada pengelola tersebut untuk menjalankan kegiatan perusahaan (Sujarweni, 2016:1).

\subsection{Akuntansi Keuangan}

Menurut Hery (2012:8), akuntansi keuangan lebih berfokus pada pelaporan informasi untuk pengguna eksternal, seperti investor, kreditur, lembaga pemerintah dan pemasok. Akuntansi keuangan berorientasi pada pelaporan pihak eksternal. Beragamnya pihak eksternal dengan tujuan spesifik bagi masing - masing pihak membuat pihak penyusun laporan keuangan menggunakan prinsip dan asumsi - asumsi dalam penyusunan laporan keuangan. 
Kieso et al, (2011:4), mendefinisikan akuntansi keuangan sebagai proses yang berpuncak pada penyiapan laporan keuangan pada perusahaan untuk digunakan oleh baik pihak internal maupun pihak eksternal.

\subsection{Pengendalian Internal}

Menurut Hery (2015:159) Pengendalian internal adalah seperangkat kebijakan dan prosedur untuk melindungi asset atau kekayaan perusahaan dari segala bentuk tindakan penyalahgunaan, menjamin tersedianya informasi akuntansi perusahaan yang akurat, serta memastikan bahwa semua ketentuan (peraturan) hukum/undang-undang serta kebijakan manajemen telah dipatuhi atau dijalankan sebagaimana mestinya oleh seluruh karyawan perusahaan. Menurut America Institute Of Certified Public Accountant (AICPA) yang kemudian dikutip oleh Midjan La dan Susanto (2011:56) pengendalian internal meliputi struktur organisasi dan segala cara serta tindakan dalam suatu perusahaan yang saling terkoordinasi dengan tujuan mengamankan harta kekayaan perusahaan, menguji ketelitian dan kebenaran data akuntansi, meningkatkan efisiensi operasi serta mendorong ketaatan terhadap kebijakan - kebijakan yang telah digariskan oleh pimpinan perusahaan.

Menurut Anastasia dan Lilis (2011:82) pengendalian internal adalah rencana organisasional, metode dan pengukuran yang dipilih oleh suatu kegiatan usaha untuk mengamankan harta kekayaannya, mengecek keakuratan dan keandalan data akuntansi usaha tersebut, meningkatkan efisiensi operasional dan mendukung dipatuhinya kebijakan manajerial yang telah ditetapkan.

\subsubsection{Tujuan Pengendalian Internal}

Menurut COSO dikutip oleh Susanto (2013:95), pengendalian internal dapat didefinisikan sebagai suatu proses yang dipengaruhi oleh dewan direksi manajemen dan karyawan yang dirancang untuk memberikan jaminan yang meyakinkan bahwa tujuan organisasi akan dapat dicapai melalui hal - hal berikut:

1. Efisiensi dan efektivitas operasi

2. Penyajian laporan keuangan yang dapat dipercaya

3. Ketaatan terhadap undang - undang dan aturan yang berlaku

Menurut Sujarweni (2015:69), tujuan utama perusahaan membuat system pengendalian internal adalah sebagai berikut:

1. Untuk menjaga kekayaan perusahaan

2. Untuk menjaga keakuratan laporan keuangan

3. Untuk menjaga kelancaran operasi perusahaan

4. Untuk menjaga kedisiplinan dipatuhinya kebijakan manajemen

5. Untuk lapisan yang ada diperusahaan tunduk pada hukum dan aturan yang sudah ditetapkan oleh perusahaan.

\subsubsection{Komponen Pengendalian Internal}

Kerangka pengendalian internal yang paling banyak diterima di A.S dikeluarkan oleh Commite Of Sponsoring Organizations (COSO). Komponen pengendalian internal COSO (Arens A. Alvin, 2012:320), sebagai berikut:

1. Lingkungan Pengendalian Lingkungan pengendalian internal terdiri dari tindakan, kebijakan dan prosedur menggambarkan keseluruhan sikap manajemen, direksi, dan pemilik dari suatu entitas atas pengendalian internal dan pentingnya pengendalian internal tersebut terhadap entitas.

2. Penilai Resiko

Menilai resiko merupakan komponen kedua dari pengendalian internal. Penilaian reiko merupakan kegiatan yang dilakukan oleh manajemen dalam mengidentifikasi dan menganalisis resiko yang menghambat perusahaan dalam mencapai tujuannya. 
3. Aktivitas Pengendalian

Akitivitas pengendalian merupakan kebijakan dan prosedur. Kemungkinan terdapat banyak aktivitas pengendalian pada setiap entitas, termasuk pengendalian secara manual dan pengendalian secara otomatis.

4. Informasi dan Komunikasi

Tujuan dari system informasi dan komunikasi akuntansi suatu entitas adalah untuk memulai, mencatat, memproses dan melaporkan transaksi - transaksi yang terjadi dalam suatu entitas dan untuk menjaga akuntabilitas asset - asset yang terkait.

5. Pengawasan

Aktivitas pengawasan berkaitan dengan penilaian yang berjalan atau penilaian berkala atas kualitas pengendalian internal oleh manajemen untuk menentukan bahwa pengendalian dijalankan sesuai dengan tujuannya dan dimodifikasi jika diperlukan terjadi perubahan kondisi.

\subsubsection{Contoh Utama Pengendalian Internal}

Menurut Hery (2015:160) ada beberapa contoh utama yang memerlukan pengendalian internal secara baik yaitu:

1. Pengupahan dan penggajian

2. Pemesanan dan pembelian barang

3. Pengiriman dan penjualan barang dagangan

4. Penerimaan dan pembayaran kas

5. Penyimpanan barang dagangan di gudang

6. Penanganan atas asset tetap

7. Dan lain - lain.

\subsubsection{Prinsip - prinsip Pengendalian Internal}

Untuk mengamankan asset dan meningkatkan keakuratan serta keandalan catatan (informasi) akuntansi, perusahaan biasanya akan menerapkan 5 (lima) prinsip pengendalian internal tertentu. Masing - masing prinsip pengendalian internal akan dijelaskan sebagai berikut:

1. Penetapan Tanggung jawab

2. Pemisahan Tugas

3. Dokumentasi

4. Pengendalian Fisik, Mekanik, dan Elektronik

5. Pengecekan Indenpenden atau Verifikasi Internal

\subsubsection{Keterbatasan Pengendalian Internal}

Sistem pengendalian internal perusahaan pada umunya dirancang untuk memberikan jaminan yang memadai bahwa asset perusahaan telah diamankan secara tepat dan bahwa catatan akuntansi dapat diandalkan.

\subsection{Pengertian Kredit Cepat Aman (KCA)}

Produk KCA ini merupakan system gadai yang diperuntukkan ke semua nasabah, baik itu untuk kebutuhan konsumtif ataupun produktif. KCA adalah solusi terpercaya bagi anda yang ingin mendapatkan pinjaman dengan cara mudah, aman, serta cepat.

\subsubsection{Keunggulan Produk KCA}

1. Layanan produk ini ada di semua outlet Pegadaian di seluruh pelosok Indonesia.

2. Prosedur yang dijalankan bisa dibilang sangat mudah, nasabah hanya cukup membawa agunan atau jaminan ke outlet.

3. Proses pencairan tidak memakan waktu yang lama, kurang lebih 15 menit dana itu akan cair.

4. Pinjaman bisa dari Rp 50. 000 hingga Rp 200.000.000 lebih tergantung kepada agunan yang telah diajukan pihak nasabah. 
5. Jangka waktu pinjaman paling lama hanya empat bulan atau seratus dua puluh hari, serta dapat dilakukan perpanjangan dengan hanya membayar sewa modal saja atau bisa disebut dengan mengangsur sebagian uang pinjaman.

6. Pelunasan bias dilakukan kapan saja tanpa adanya batasan waktu.

7. Tidak memerlukan rekening.

8. Nasabah mendapatkan pinjaman berbentuk uang tunai.

\subsubsection{Syarat Mengajukan KCA}

1. Menyerahkan agunan atau jaminan berupa barang berharga (misalnya emas).

2. Fotokopi KTP ataupun identitas diri lainnya.

3. Jika agunan tersebut berupa kendaraan, maka harus membawa BPKB dan STNK asli.

4. Nasabah diharuskan menandatangani SBK (Surat Bukti Kredit).

\subsubsection{Pengertian Gadai Secara Umum}

Secara umum pengertian usaha gadai adalah kegiatan menjaminkan barang - barang berharga kepada pihak tertentu, guna memperoleh sejumlah uang dan barang yang dijaminkan akan ditebus kembali sesuai dengan perjanjian antara nasabah dan pegadaian.

\section{METODE PENELITIAN}

\subsection{Jenis Penelitian}

Jenis penelitian yang dilakukan adalah penelitian deskriptif yaitu, penelitian yang meliputi pengumpulan data untuk diuji hipotesis atau menjawab pertanyaan mengenai status terakhir dari subjek penelitian.

\subsection{Tempat dan Waktu Penelitian}

Penelitian ini dilaksanakan di PT. Pegadaian (PERSERO) Cabang Mega Mas Manado terletak di Jl. Pierre Tendean Boulevard Manado Sulawesi Utara - Indonesia No Telp. 08114302132. Dengan waktu penelitian dimulai dari bulan agustus 2017 sampai dengan selesai.

\subsection{Teknik Pengumpulan Data} berikut :

Metode pengumpulan data yang digunakan dalam penelitian ini adalah sebagai

1. Teknik Wawancara, menurut Emzir (2014:50) dapat didefinisikan sebagai interkasi bahasa yang berlangsung antara dua orang dalam situasi saling berhadapan salah seorang, yaitu yang melakukan wawancara meminta informasi atau ungkapan kepada orang yang diteliti yang berputar di sekitar pendapat dan keyakinannya.

2. Observasi, yaitu teknik pengumpulan data dengan mengumpulkan dan mengadakan pengamatan langsung terhadap pelaksanaan operasi perusahaan pada objek untuk memperoleh gambaran yang jelas mengenai fakta dan kondisi di lapangan.

3. Dokumentasi, merupakan salah metode pengumpulan data yang dilakukan peneliti untuk mendapatkan gambaran dari sudut pandang subjek melalui media tertulis atau dokumen lainnya yang tertulis atau dibuat langsung oleh subjek yang bersangkutan

\subsection{Metode Analisis}

Metode analisis data yang digunakan atau diterapkan untuk menganalisis dalam penelitian ini adalah metode analisis deskriptif yaitu metode yang dilakukan dengan cara menguraikan, menggambarkan, membandingkan, dan menerangkan suatu keadaan yang bertujuan untuk mendapatkan gambaran yang jelas dan terperinci mengenai suatu keadaan berdasarkan data atau informasi yang telah didapatkan, kemudian mengambil kesimpulan dan selanjutnya memberikan saran dari hasil perbandingan tersebut. 


\section{HASIL ANALISIS DAN PEMBAHASAN}

\subsection{Hasil analisis}

Lingkup pembahasan atas pengendalian internal kredit cepat aman pada PT. Pegadaian Cabang Mega Mas Manado mencakup pembahasan yang berhubungan dengan unsur - unsur pengendalian internal kredit cepat aman, yaitu struktur organisasi yang memisahkan tanggung jawab fungsional secara tegas, system wewenang dan prosedur pencatatan yang memberikan perlindungan yang cukup terhadap kekayaan, utang, pendapatan dan biaya, praktik yang sehat dalam melaksanakan tugas dan funsi setiap unit organisasi serta karyawan yang mutunya sesuai dengan tanggungjawabnya.

\section{Lingkungan Pengendalian}

a) Integritas dan nilai etika:

Pada PT Pegadaian cabang mega mas manado, memiliki motivasi giat dalam melaksanakan tugas yang telah dipercayakan.

b) Komitmen terhadap kompetensi:

Pada PT Pegadaian cabang mega mas manado, manajemen menjunjung tinggi integritas dan kompetensi.

c) Filosofi dan gaya manajemen:

Pada PT Pegadaian cabang mega mas manado, pihak manajemen menilai potensi risiko.

d) Struktur organisasi:

Struktur organisasi ini telah dirancang dan disusun dengan baik oleh PT Pegadaian

e) Penetapan wewenang dan tanggung jawab:

Pada PT Pegadaian cabang mega mas manado, kondisi ini dapat dilihat dengan adanya pemisahan fungsi dan wewenang kepada setiap anggota.

2. Penilai Resiko

PT. Pegadaian Cabang Mega Mas Manado selalu melakukan penilaian risiko terhadap karyawan.

\section{Pengendalian Lingkungan}

Pengendalian aktivitas adalah tindakan-tindakan yang ditetapkan melalui kebijakan dan prosedur yang membantu memastikan bahwa arahan manajemen untuk mengurangi resiko terhadap pencapaian. Pada PT. Pegadaian Cabang Mega Mas Manado pengendalian aktivitas telah diterapkan berdasarkan komponen COSO yaitu: (a) Sistem otorisasi dan prosedur, (b) Pemisahan tugas, (c) Karyawan yang kompeten.

\section{Informasi dan Komunikasi}

PT. Pegadaian Cabang Mega Mas Manado telah menerapkan komponen pengendalian informasi dan komunikasi. Hal itu dapat dilihat dengan adanya surat permohonan kredit.

\section{Pengawasan}

Pada PT. Pegadaian Cabang Mega Mas Manado yang mengawasi pengendalian internal yaitu kepala cabang. 


\subsection{Pembahasan}

Berikut ini merupakan penerapan pengendalian internal menurut COSO pada PT.

Pegadaian Cabang Mega Mas Manado:

\begin{tabular}{l} 
Teori Coso \\
\hline 1. Lingkungan \\
Pengendalian \\
Lingkungan pengendalian a. \\
adalah pembentukan \\
suasana organisasi serta \\
memberi kesadaran tentang \\
perlunya pengendalian bagi \\
suatu organisasi ada b. \\
beberapa factor yang \\
mempengaruhi lingkungan \\
pengendalian adalah \\
sebagai berikut:
\end{tabular}

1) Integritas dan nilai etika

2) Komitmen terhadap kompetensi

3) Partisipasi dewan direksi dan komite audit

4) Filosofi dan gaya manajemen

5) Struktur organisasi

6) Kebijakan dan praktik sumber daya manusia

\section{PT Pegadaian}

1. Lingkungan Pengendalian

a. Integritas dan nilai etika :

Pada PT Pegadaian cabang mega mas manado, sudah baik

b. Komitmen terhadap kompetensi:

Pada PT Pegadaian cabang mega mas manado, sudah baik Filosofi dan gaya manajemen :

Pada PT Pegadaian cabang mega mas manado, sudah baik

d. Struktur organisasi : Struktur organisasi ini telah dirancang dan disusun dengan baik oleh PT Pegadaian

e. Penetapan wewenang dan tanggung jawab pada PT Pegadaian cabang mega mas manado, sudah baik

\section{Y. Yaitu seperti memiliki}

a. Yaitu seperti memiliki motivasi giat dalam melaksanakan tugas yang telah dipercayakan, dan jujur ketika melaksanakan tugas tanpa pengaruhpengaruh dari pihak tidak berkepentingan.

b. Manajemen PT Pegadaian menunjung tinggi integritas dan kompetensi. Antara bagian yang satu dengan lainnya di dalam perusahaan merupakan satu kesatuan yang saling berhubungan. Setiap karyawan memiliki kompetensi. Perekrutan calon karyawan yang berkualitas merupakan tonggok awal terciptanya kompetensi. Perusahaan memiliki Standart Operating Procedure (SOP) yang harus dijalankan oleh setiap personil. SOP tersebut berbeda untuk masing-masing bagian, karena job description setiap bagian juga berbeda. Pegawai yang dikerjakan pada perusahaan telah melewati tahap seleksi dan ditugaskan sesuai dengan kemampuannya masingmasing.

c. Yaitu pihak manajemen menilai potensi risiko dan juga pimpinan sudah berupaya untuk menghilangkan manipulasi yang biasanya dilakukan terhadap ukuran kinerja seperti dorongan dan godaan kepada karyawan untuk bersikap tidak jujur dalam menjalankan tugasnya.

d. Struktur organisasi disusun sesuai fungsionalnya, yaitu terdiri dari bagian penjualan, bagian administrasi keuangan, dan bagian umum. Penyusunan struktur organisasi berdasarkan fungsi ini sesuai untuk perusahaan seperti PT Pegadaian karena akan terlihat dengan jelas. Dari setiap bagian yang ada di perusahaan, sehingga pengendalian dapat dilakukan dengan lebih baik lagi di PT Pegadaian. Organisasi memberikan penjelasan tentang pemisahan fungsi dan tanggung jawab antar fungsi.

e. Kondisi ini dapat dilihat dengan adanya pemisahan fungsi dan wewenang kepada setiap anggota 


\begin{tabular}{|c|c|c|}
\hline Teori Coso & PT Pegadaian & Keterangan \\
\hline & & $\begin{array}{l}\text { perusahaan sesuai dengan kemampuan } \\
\text { dan keterampilan yang dimiliki. Fungsi } \\
\text { penjualan telah dilakukan oleh bagian } \\
\text { kasir, pada sisi yang terkait dalam } \\
\text { penerimaan kas sudah baik dan tidak } \\
\text { menggunakan pembenahan. } \\
\text { f. Pegawai yang dipekerjakan pada } \\
\text { perusahaan telah melewati tahap } \\
\text { seleksi danditugaskan sesuai dengan } \\
\text { kemampuannya masing-masing. }\end{array}$ \\
\hline 2. Penilaian Resiko & $\begin{array}{l}\text { 2. Penilaian Resiko } \\
\text { Resiko penilaian } \\
\text { yang dilakukan } \\
\text { oleh manajemen } \\
\text { dengan } \\
\text { menggunakan } \\
\text { system untuk } \\
\text { meminimalisir } \\
\text { resiko yang akan } \\
\text { terjadi sudah baik. }\end{array}$ & $\begin{array}{l}\text { Agar supaya nasabah apabila } \\
\text { menerima telepon/sms dari } \\
\text { pegadaian maka langsung segera hubungi } \\
\text { pihak pegadaian. Agar supaya } \\
\text { menimbulkan resiko yang sudah } \\
\text { diterapkan dipegadaian sebelumnya, yaitu } \\
\text { pelelangan barang apabila sudah melewati } \\
\text { jatuh tempo. }\end{array}$ \\
\hline $\begin{array}{l}\text { 3. Pengendalian Aktivitas } \\
\text { pengendalian aktivitas } \\
\text { adalah tindakan-tindakan } \\
\text { yang ditetapkan melalui } \\
\text { kebijakan dan prosedur } \\
\text { yang membantu } \\
\text { memastikan bahwa } \\
\text { arahan manajemen untuk } \\
\text { mengurangi resiko } \\
\text { terhadap pencapaian. } \\
\text { Pengendalian aktivitas } \\
\text { dilakukan pada semua } \\
\text { tingkat entitas, pada } \\
\text { berbagai tahap dalam } \\
\text { proses bisnis, dan atas } \\
\text { lingkungan teknologi. } \\
\text { a. System Otorisasi dan } \\
\text { Prosedur } \\
\text { b. Pemisahan tugas } \\
\text { c. Karyawan yang } \\
\text { kompeten. }\end{array}$ & $\begin{array}{l}\text { 3. Pengendalian } \\
\text { Aktivitas } \\
\text { Aktivitas } \\
\text { pengendalian yang } \\
\text { dilakukan terhadap } \\
\text { system informasi } \\
\text { akuntansi juga } \\
\text { sudah baik. }\end{array}$ & $\begin{array}{l}\text { a. System otorisasi dan prosedur } \\
\text { penggadaian dan pelelangan diotorisasi } \\
\text { oleh bagian kasir dengan } \\
\text { membubuhkan kuitansi pengkreditan } \\
\text { barang. } \\
\text { b. Pemisahan tugas oleh masing-masing } \\
\text { bagian atau fungsi. } \\
\text { c. Karyawan yang kompeten dalam } \\
\text { bidangnya dapat dilihat dari kebijakan } \\
\text { manajemen, yaitu berupa prosedur } \\
\text { perekrutan calon karyawan dengan } \\
\text { selektif melalui tahap-tahap sesuai } \\
\text { dengan bidangnya, misalnya minimal } \\
\text { kelulusan SMA untuk staff laki-laki } \\
\text { dan strata satu (S1) untuk staff } \\
\text { perempuan. }\end{array}$ \\
\hline $\begin{array}{l}\text { 4. Informasi dan } \\
\text { Komunikasi } \\
\text { Menjelaskan bahwa } \\
\text { informasi sangat penting } \\
\text { bagi setiap entitas untuk } \\
\text { melaksanakan tanggung } \\
\text { jawab penegendalian } \\
\text { internal juga mendukung } \\
\text { pemcapaian } r \text { tujuan- } \\
\text { tujuannya. Informasi } \\
\text { yang } \quad \text { diperlukan } \\
\end{array}$ & 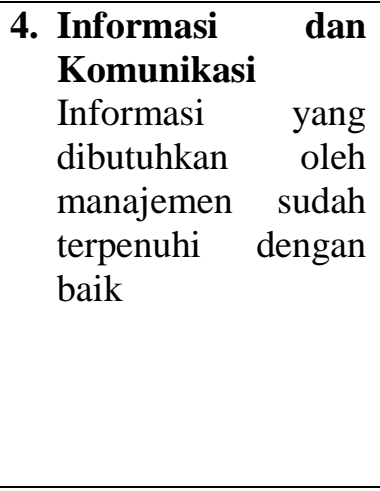 & $\begin{array}{l}\text { System informasi dan komunikasi dalam } \\
\text { pelaksanaan kegiatan perusahaan } \\
\text { melibatkan fungsi yang terkait, prosedur } \\
\text { yang harus diikuti, dokumen dan catatan } \\
\text { yang diperlukan serta laporan yang } \\
\text { dihasilkan. Pencatatan kedalam catatan } \\
\text { akuntansi harus didasarkan atas laporan } \\
\text { sumber yang dilampiri dengan dokumen } \\
\text { pendukung yang lengkap yang telah } \\
\text { diotorisasi oleh pihak yang berwenang. } \\
\text { Uang diterima apabila nasabah sudah }\end{array}$ \\
\hline
\end{tabular}




\begin{tabular}{|c|c|c|}
\hline Teori Coso & PT Pegadaian & Keterangan \\
\hline $\begin{array}{lr}\text { manajemen } & \text { adalah } \\
\text { informasi yang relevan } \\
\text { dan berkualitas baik } \\
\text { yang berasal dari sumber } \\
\text { internal maupun } \\
\text { eksternal dan informasi } \\
\text { yang digunakan untuk } \\
\text { mendukung fungsi } \\
\text { komponen-komponen } \\
\text { lain pengendalian } \\
\text { internal. Informasi } \\
\text { diperoleh ataupun } \\
\text { dihasilkan melalui } \\
\text { proses komunikasi antar } \\
\text { pihak internal mapun } \\
\text { eksternal yang dilakukan } \\
\text { secara terus-menerus, } \\
\text { berulang, dan berbagi. } \\
\text { Kebanyakan organisasi } \\
\text { membangun suatu } \\
\text { system informasi untuk } \\
\text { memenuhi kebutuhan } \\
\text { informasi yang andal, } \\
\text { relevan dan tepat waktu. }\end{array}$ & & $\begin{array}{l}\text { mengisi formulir dan memberikan barang } \\
\text { jaminannya kemudian penaksir menaksir } \\
\text { dan menentukan jumlah barang yang } \\
\text { digadaikan. }\end{array}$ \\
\hline 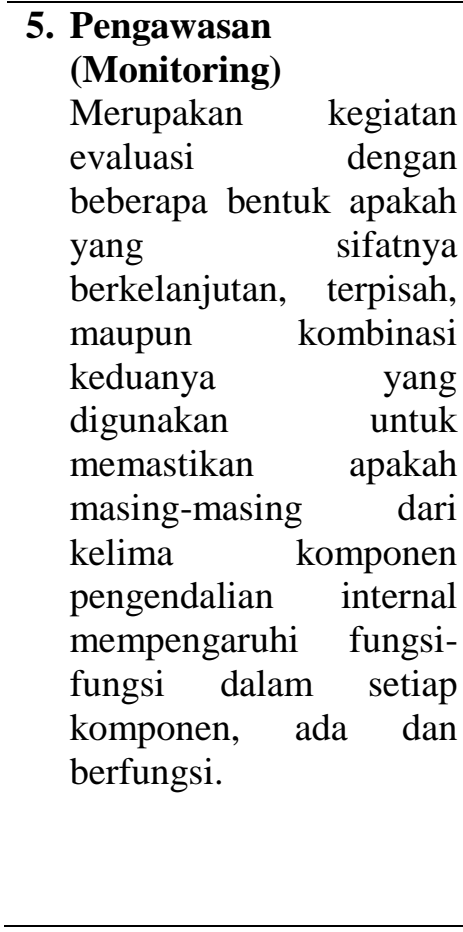 & $\begin{array}{l}\text { 5. Pengawasan } \\
\text { (Monitoring) } \\
\text { Aktivitas } \\
\text { pengawasan } \\
\text { terhadap } \\
\text { pengendalian intern } \\
\text { seistem informasi } \\
\text { akuntansi penjualan } \\
\text { tunai telah berjalan } \\
\text { dengan baik dan } \\
\text { efektif. }\end{array}$ & $\begin{array}{l}\text { dalam perusahaan PT Pegadaian cabang } \\
\text { mega mas manado yang mengawasi } \\
\text { pengendalian internal yaitu kepala } \\
\text { cabang. Beberapa bagian yang diawasi } \\
\text { adalah bagian penaksir, bagian penjualan, } \\
\text { bagian administrasi, bagian penglelangan } \\
\text { emas, dan bagian keuangan dan umum, } \\
\text { dilakukan agar dapat membantu } \\
\text { manajemen untuk mengetahui } \\
\text { ketidakefektifan pelaksanaan unsur-unsur } \\
\text { pengendalian internal pada PT Pegadaian } \\
\text { melakukan pengawasan dengan cara } \\
\text { evaluasi agar penyimpangan yang } \\
\text { ditemukan juga merupakan tanggapan } \\
\text { yang baik dan mencerminkan adanya } \\
\text { kesadaran akan pentingnya pengendalian } \\
\text { yang tertanam dalam diri manajemen. Jadi } \\
\text { secara tertulis aktivitas pengawasan yang } \\
\text { dilakukan sudah cukup baik dalam } \\
\text { mendukung terciptanya pengendalian } \\
\text { internal yang memadai dalam perusahaan. }\end{array}$ \\
\hline
\end{tabular}

\section{KESIMPULAN DAN SARAN}

\subsection{Kesimpulan}

Berdasarkan hasil penelitian dan pembahasan yang telah diuraikan pada bab sebelumnya maka dapat disimpulkan bahwa pengendalian internal kredit cepat aman pada PT. Pegadaian Cabang Mega Mas Manado adalah sangat baik. Hal ini dapat dilihat dari:

1. Secara umum lingkungan pengendalian menurut teori COSO pada PT. Pegadaian cabang mega mas manado sudah baik. 
2. Penilaian resiko di pengendalian internal menurut teori COSO pada PT. Pegadaian cabang mega mas manado sudah baik.

3. Pengendalian aktivitas di pengendalian internal menurut teori COSO pada PT. Pegadaian cabang mega mas manado sudah baik.

4. Informasi dan komunikasi di pengendalian internal menurut teori COSO pada PT. Pegadaian cabang mega mas manado sudah baik.

5. Pengawasan di pengendalian internal ini menurut teori COSO pada PT. Pegadaian cabang mega mas manado sudah berjalan dengan baik.

\subsection{Saran}

Berdasarkan hasil pembahasan serta kesimpulan yang telah diuraikan, maka saran yang dapat diberikan kepada PT. Pegadaian Cabang Mega Mas Manado adalah sebagai berikut:

1. Dengan pengendalian internal yang sudah baik diharapkan PT. Pegadaian Cabang Mega Mas Manado dapat mempertahankan hal tersebut dan lebih meningkatkan pelayanan pada nasabah.

2. Agar dilakukan pemisahan fungsi, antara fungsi operasi dan fungsi akuntansi. Sehingga apabila telah dilakukan pemisahan fungsi antara fungsi operasi dan fungsi akuntansi akan dapat meningkatkan pengendalian internal kredit cepat aman dalam pelaksanaan operasional perusahaan.

3. Untuk posisi agar menerima karyawan baru bagi perempuan dengan tingkat pendidikan minimal SMA sesuai dengan ketentuan yang ditetapkan perusahaan.

\section{DAFTAR PUSTAKA}

Abdullah. 2012. Akuntansi Biaya. Penerbit Salemba Empat. Jakarta.

Anastasia dan Lilis. 2011. Sistem Informasi Akuntansi, Perancangan, Proses dan Penerapan. Edisi I. Yogyakarta.

Emzir. 2014. Metodologi Penelitian Kualitatif Analisis Data, Cetakan Empat. Penerbit Rajawali Pers. Jakarta.

Hery. 2012. Akuntansi Keuangan Menengah I. Penerbit PT. Bumi Aksara. Jakarta.

Hery, 2015, Pengantar Akuntansi. Penerbit PT. Grasindo, Jakarta.

Kieso, et al. 2011. Intermediate Accounting, Jilid 1 Edisi k-12. Penerbit Erlangga. Jakarta.

Pedoman Kantor Cabang, Pedoman Operasional Kantor Cabang (POKC), Penerbit

Kantor Pusat PT. Pegadaian, Jakarta.

Pontoh. 2013. Akuntansi Konsep dan Praktik. Penerbit Halaman Moeka. Jakarta Barat.

Rahman, Pura. 2013. Pengantar Akuntansi I. Penerbit Erlangga.

Sujarweni. 2015. Akuntansi Sektor Publik. Penerbit Pustaka Baru Press.

Sujarweni. 2016. Pengantar Akuntansi. Penerbit Pustaka Baru Pres. Yogyakarta.

Susanto. 2013. Sistem Informasi Akuntansi, Cetakan Pertama. Penerbit Lingga Jaya. Bandung. 